\title{
Necessity and Obligation Modals in English Academic Discourse: A Corpus-Based Analysis
}

\author{
Ikmi Nur Oktavianti \\ Universitas Ahmad Dahlan, Indonesia \\ e-mail:ikmi.oktavianti@pbi.uad.ac.id
}

\begin{abstract}
:
Modals are linguistic units that seem to be ubiquitous in nearly all genres and text categories. However, there are some tendencies in which some modals are more likely to occur in a particular text category than the others. It is said that modals are less frequent in academic texts compared to fiction and news. This paper then aims at describing the modals, focusing to those expressing necessity/obligation, by using corpus-based analysis. This study uses a general reference corpus, Corpus of Contemporary American English, and compiled the data from the academic subcorpus. The results show that statistically the usage frequency of necessity and obligation modals is negligible; however, no matter how small it is, it still purports to mark something. Among the modals in the same category there are some tendencies, e.g. modal should is the most frequent of all, followed by must, have to, shall, be supposed to, and have got to. The collocate analysis focuses on should and must and found out that the most frequent verb type following these two modals belong to thinking verbs (e.g., consider, learn, understand). However the most frequent modal constructions are should have and must have enabling a slightly different interpretation. Besides, due to the nature of language in an academic setting, it is thus predictable that the use of the core modals (e.g., should, must) is more frequent than the quasi-modals (e.g., have to).
\end{abstract}

Keywords: academic text, corpus, , modals, necessity, obligation

\section{Introduction}

Studying language use in different genres and text categories is perpetually appealing as each genre and category has its own linguistic characteristics. The language used in literary works (e.g., prose and poetry) concerns more on the aesthetic aspect as the author manipulatively use the linguistic code (Leech \& Short, 2007). In news text, language style is prominent to build up the newsworthiness (Bednarek \& Caple, 2012). Both fiction and news, however, attempt to be closer to their readers. Unlike fiction and news, academic discourse is perceived as obtuse text 
category due to the choice of words and complex grammatical structure (Biber \& Gray, 2016). Although basically news and academic discourse have a similar purpose to deliver information (Biber \& Conrad, 2009), it turns out that they have rather discrete characteristics. Regarding the communicative purpose, academic discourse involves interpretation, while news primarily focuses on factual reporting (Biber \& Conrad, 2009). If news and fiction purport to be close to the readers, thus everyday language is preferable; however, academic texts (the term academic texts and academic discourse in this study are used interchangeably) primarily see things differently. In academic discourse, events are perceived as a network of cause and event, different from fiction and news who perceive events as sequence (Hyland, 2009, p. 7). It is interesting then to further study academic discourse, especially relating to the use of a certain linguistic unit in academic texts.

Regarding the use of linguistic units, Biber \& Conrad (2009, pp. 115-117) and Biber \& Quirk (2012) have identified several linguistic features of different text categories, also in academic texts, including the use of modals to manifest modality expressions (e.g., permission, possibility, ability, obligation, necessity, prediction, volition). Biber \& Conrad (2009) state that modals are most frequently used in fiction and least frequently found in news, to make academic discourse in between. Meanwhile, Oktavianti (2019) finds out that the use of modals is more frequently used in news text than in academic discourse. Despite the different description of usage frequency of modals in distinct text categories, Biber \& Conrad (2009) and Oktavianti (2019) agree that modals may and can are the most commonly used in academic discourse, even though Oktavianti (2019) mentions further details of the modals, such as would and will that are frequently used in academic texts. Those modals, based on some observations, serve as practical means of hedging in academic writing (Dudley-Evans, 1994; Hardjanto, 2016; Hyland, 1994, 1998).

Considering that modals are quite important units in academic writing, hence there have been some previous studies on modals in academic discourse. Despite what has been carried out by Biber \& Conrad (2009) and Biber \& Quirk (2012), there are some studies focusing on modals used by non-native speakers of English compared to the native speakers (Gabrielatos \& McEnery, 2005; Hinkel, 2009; Hykes, 2000; Yamamoto, 1999), the use of modals as means of hedging strategy in academic writing (Dudley-Evans, 1994; Hardjanto, 2016; among others), cross-linguistic variation of modal use (see Carrió-pastor, 2007), and comparing the use of modals by English foreign learner to an English corpus (Mcenery \& Kifle, 2001; Yang, 2018). Previous studies on necessity/obligation modals were carried out by analyzing the use of the modals in different English varieties through corpus investigation (Daugs, 2017; Rajalahti, 2006; Tagliamonte \& D’Arcy, 2007). Nevertheless, little is known about other types of modality expressions (e.g., necessity/obligation) in academic context. Whereas, using necessity/obligation modals is inevitably important due to the function to emphasize necessity and expose obligation in academic writing (Yamamoto, 1999). This study then aims at investigating the frequency of use of necessity/obligation modals in academic texts and how they are used in an academic corpus as the representation of actual language use. It is intriguing to find out the answer to these questions so that this study can complement the available studies on modals in academic context. Nonetheless, this study focuses merely on some necessity/obligation modals; they are core modals shall, must, and should, quasi-modals have to, have got to, and be supposed to. 
Furthermore, this study takes no account of the pragmatic aspect of the necessity/obligation modals; the terms epistemic, deontic, dynamic, thus are ignored.

\section{Literature Review}

The nature of necessity/obligation modals is also salient to take into account before analyzing the frequency and so forth. Gahér (2003) argues that necessity embodies truth-value proposition. In the Oxford Dictionary of English (2014), necessity is defined as "the state or fact of being required". The term obligation implies legal and moral (Allen, 1980; Zimmerman, 1996). Thus, in the Oxford Dictionary of English, (2014), an obligation is defined as "an act or course of action to which a person is morally or legally bound; a duty or commitment". Firmly related to 'obligation', the term 'necessity', Collins (2014) groups obligation and necessity meaning into one, assuming that the meanings are basically related and the modals expressing those meanings are somewhat overlapping.

Modals that belong to this meaning category are-among others-shall, must, should, have to, have got to, and be supposed to. Core modal shall is identified as having the strongest obligation meaning as it also ensures that the action is carried out (Palmer, 1990), so it is preferable to be used in legal documents. Even though shall has polysemous meanings, yet the original meaning is to state obligation (Tagliamonte, 2013, p. 123). Other core modals under this category are should and must. Based on Collins (2014) and Palmer (1990), modal should is an internal obligation, yet it is more likely to be used as suggestion (Eastwood, 2002; Murphy, 2012). Therefore the meaning is not as strong as must (Murphy, 2012, p. 66). Interestingly core modal must is also likely to be used to show logical conclusion instead of obligation. Collins (2009, p. 60) says that the difference of must and have to lies in the context of immediacy. Other periphrastic modals under this category are have got to and be supposed to (Collins, 2009; Palmer, 1990). According to Palmer and Collins, the meaning of have got to is as vigorous as must, as is observed in Historical Thesaurus of English. As for be supposed to, it is assumed to show a more objective meaning-similar to ought to, although be supposed to is more frequently used than ought to (Collins, 2009, p. 81).

\section{Research Methodology}

This study uses a synchronic corpus, namely Corpus of Contemporary American English or COCA (Davies, 2008). The primary reasons of selecting COA are due to its large size (comprising 560 million words), its updated compilation (the latest compilation is from 2017), and its availability of academic subcorpus (comprising 112 million words). Some other corpora might have larger size (e.g., GloWbe, iWeb), but they are not updated, and they focus on varieties of English and Internet language. Although there is a specific corpus for academic English, e.g. Michigan Corpus of Upper Level Students Papers, it only comprises 2,6 million words, smaller than subcorpus academic of COCA, and it is outdated since it is compiled from 2002 to 2009.

The data were collected from academic subcorpus of COCA by using keywords search. By keywords, there are several English necessity/obligation modals, such as must, have to, have got to, be supposed to. The qualitative data are the collocates of the modals under study and the quantitative data are the frequency of use of those modals. The analysis of the data was also carried out differently for different types of data. The qualitative data were analyzed semantically by classifying the verbs into types of verbs, referring to the classification of primary verb types by 
Dixon as in table 1. For instance, a verb collocate identified in the corpus, learn, is classified into thinking verb, since it deals with thinking activity.

Table 1. Dixon's primary verb types

\begin{tabular}{|l|l|l|}
\hline \multirow{2}{*}{ Primary A } & Verb type & \multicolumn{1}{c|}{ Examples } \\
\cline { 2 - 3 } & Motion and rest & move, walk, follow, stand \\
\cline { 2 - 3 } & Affect & touch, kick, hit, knock \\
\cline { 2 - 3 } & Corporeal & supply, serve, contribute, deliver \\
\cline { 2 - 3 } & Weather & eat, smoke, scrub, sleep \\
\cline { 2 - 3 } & Competition & rain, thunder \\
\cline { 2 - 3 } & Social contract & fight, race, win, attack \\
\cline { 2 - 3 } & Using & manage, promote, nominate, punish \\
\cline { 2 - 3 } & Obeying & use, operate, wear, waste \\
\hline Primary B & Attention & See, hear, notice, smell \\
\cline { 2 - 3 } & Thinking & think, consider, understand, know \\
\cline { 2 - 3 } & Deciding & decide, select, choose, prefer \\
\cline { 2 - 3 } & Speaking & say, tell, talk, speak, discuss \\
\cline { 2 - 3 } & Liking & like, want, enjoy, approve \\
\cline { 2 - 3 } & Annoying & frighten, shock, annoy, trouble \\
\cline { 2 - 3 } & Acting & act, behave, copy, imitate \\
\cline { 2 - 3 } & Happening & include, compare, comprise, differ \\
\hline & Comparing & depend (on), indicate, demonstrate \\
\cline { 2 - 3 } & Relating &
\end{tabular}

This classification of verb types is selected in this study due to its ability of being not too concrete (that makes the classification too difficult) or too simple (that doesn't show the nature of verbs). There are some other classifications of verbs, but they are too concrete (Levin, 1993), too simple (Chafe, 1970), or too abstract (Pavey, 2010) for text analysis. As for the quantitative data, they were normalized (see Brezina, 2018). The base of normalization used in this research is per one million words. To minimalize mistake and to obtain valid results, the counting of normalized frequency (nf) used a feature available in COCA (frequency per one million words). In making this study more comprehensive, there is also an interpretation of the frequency and the available theory on necessity and obligation modals to reveal the dynamic use of the modals. The interpretation followed thick description model proposed by Geertz (Stake, 2010) by taking advantage of the frequencies, the relevant theories, and the assistance from another corpus, British National Corpus (Davies, 2004), and a historical thesaurus, Historical Thesaurus of English (2016) to complement the analysis.

\section{Findings and Discussion}

The discussion covers two main analyses: usage frequency of necessity/obligation modals and the collocates of the modals as found in COCA. At the end of this section, however, the elaboration of dynamic use of the modals is inevitably necessary.

\subsection{Frequency of necessity/obligation modals in academic discourse}

This section elaborates the usage frequency of necessity/obligation modals in academic discourse, focusing on must, have to, have got to and be supposed to. According to the search results in COCA, core modal must is the most frequently used in academic discourse compared 
with other modals under study. Quasi-modal have to occupy the second rank, followed by be supposed to and have got to in the last position. Table 2 below presents the frequency.

Table 2. Frequency (nf) of necessity/obligation modals in academic discourse

\begin{tabular}{|c|l|c|}
\hline Rank & Modals & Nf \\
\hline 1 & should & 174 \\
\hline 2 & must & 121 \\
\hline 3 & have to & 64 \\
\hline 4 & shall & 11 \\
\hline 5 & be supposed to & 3.75 \\
\hline 6 & have got to & 0.75 \\
\hline
\end{tabular}

Based on table 2, it is evident that necessity/obligation expressions can still be found in academic discourse or in other words academicians still need the expressions. However, it is important to take note that the use of should dominates all other modals expressing nearly the same meaning (174 times per one million words). In the second position, core modal must is used 121 times per one million words. Following must, there is quasi-modal have to occupying the third most frequent (64 times per one million words). The comparison to other genres is appealing to show since the use of must and have to in fiction and news show contrary order in which have to is more frequently used than must, as described in table 3 below.

Table 3. Frequency (nf) of must and have to in different text categories

\begin{tabular}{|c|c|c|c|}
\hline Modals & Fiction & Academic & News \\
\hline Must & 95 & 121 & 135 \\
\hline have to & 201 & 64 & 296 \\
\hline
\end{tabular}

This difference is plausible to occur because the nature of academic language seems to be on the opposite side of fiction and news. However, this dynamic of must and have to has been identified by Collins (2009, p. 67) in his empirical research.

In the fourth position is shall that is presumably seldom to use in daily use of language. According to Leech, Hundt, Mair, \& Smith (2009), the use of shall is decreasing over the last decades so it is not surprising to identify its less frequent of use in this study. Similar to shall, be supposed to and have got to occupy the lower position-and have got to in the lowest oneamong other modals under study. Besides, have got to is identical to a colloquial context or informal conversation (Azar \& Hagen, 2016) so the use of this modal is the lowest of all in an academic context. Based on the frequency findings, it is obvious that academic discourse does not need to express strong and authoritative obligation and necessity (such as expressed by must and shall) as frequently as other modality expressions.

\subsection{The Collocates of should and must in Academic discourse}

The following discussion is about the collocates of should and must observed in COCA. Nevertheless, the collocates investigated in this study are limited to the first right collocates only (R1) or the verb collocates since grammatically modals must be followed by verbs (i.e., bare infinite verbs). Thus, it is robustly assumed that the $\mathrm{R} 1$ is occupied by verb. The following table (table 4) presents the right collocates of the modals in academic texts. 
Table 4. Right collocates of should

\begin{tabular}{|c|c|}
\hline R1 & Nf \\
\hline Have & 6.81 \\
\hline Include & 1.87 \\
\hline Take & 1.63 \\
\hline Consider & 1.61 \\
\hline Provide & 1.27 \\
\hline Make & 1.04 \\
\hline Focus & 1.00 \\
\hline Do & 0.92 \\
\hline Know & 0.83 \\
\hline Use & 0.74 \\
\hline
\end{tabular}

As shown in table 4, have occupy the second most frequent collocate of should. There are two possibilities for interpreting this construction. First, it comprises should and lexical verb have expressing suggestions for something that has not happened. Second, it might consist of should and auxiliary have, interpreted as suggestions or expectation on something happened in the past (Azar \& Hagen, 2016). Due to the hybrid status of have (both serve as lexical and functional category), this verb, for the sake of classification, is ignored. Following Dixon's primary verb types (Dixon, 2005), some of the verb collocates belong to thinking type, such as include, consider, focus, and know. The other verbs are take, provide, make, do, and use.

Table 5. Right collocates of must

\begin{tabular}{|c|c|}
\hline R1 & nf \\
\hline Have & 6.63 \\
\hline Take & 1.60 \\
\hline Make & 1.05 \\
\hline Consider & 0.92 \\
\hline Include & 0.87 \\
\hline Do & 0.85 \\
\hline Learn & 0.81 \\
\hline Understand & 0.78 \\
\hline Work & 0.74 \\
\hline Provide & 0.74 \\
\hline
\end{tabular}

Similarly, the two most frequent collocate of must is have forming must have. As in should have, the existence of have following must enable different interpretation of the modal construction. It can show obligation on something that has not happened (must and lexical verb have) or express a conclusion about what happened (past) and based on putting details and clues together and making an inference (Azar \& Hagen, 2016). Like the collocates of should, some of the collocates are classified to thinking type (e.g., consider, include, learn, understand). The copious use of this verb type in an academic text is not surprising because academic texts are firmly connected with the writing of scientific work involving thinking activities. Some other verbs identified in the corpus are take, make, do, work, and provide.

To complete the analysis, it is necessary to classify the verb collocates into verb types to provide the mapping of should and must as the representatives of necessity/obligation modals in academic discourse. 
Table 6. Verb types of the collocates

\begin{tabular}{|c|c|c|c|}
\hline Verb type & Verb & nf & Total frequency (nf) \\
\hline \multirow{4}{*}{ Thinking } & Consider & 2.74 & \multirow{2}{*}{5.35} \\
\cline { 2 - 3 } & Focus & 1 & \multirow{2}{*}{} \\
\cline { 2 - 3 } & Know & 0.83 & \multirow{2}{*}{} \\
\cline { 2 - 3 } & Learn & 0.81 & 3.23 \\
\cline { 2 - 3 } & Understand & 0.78 & 2.74 \\
\hline Motion and Rest & Take & 3.23 & 2.09 \\
\hline Comparing & Include & 2.74 & 2.01 \\
\hline Affect & make & 2.09 & 1.76 \\
\hline Giving & provide & 2.01 & 0.74 \\
\hline Happening & Do & 1.76 & 0.74 \\
\hline Using & use & 0.74 & \\
\hline Social contract & work & 0.74 & \\
\hline
\end{tabular}

Table 6 shows that the most frequent collocates of should and must belong to several types of verbs; they are thinking, motion and rest, comparing, affect, giving, happening, using, and social contract. Among all types, thinking is obviously the most frequent, and thus, the most significant collocate of necessity/obligation modals in academic context.

The underlying reason for thinking verbs being the most frequent collocates can be associated with the activity undertaken in academic context. It is known that in academic text, scientific thinking is required and thus it involves thinking activities all along. In relation to necessity/obligation modal, it is necessary to consolidate the activity of thinking (i.e., cognitive activities) to ensure the academic value. Hence it is plausible that thinking verbs dominate the collocate type of should and must in the academic setting. In the corpus, the thinking verbs include consider (2.74), focus (1), know (0.83), learn (0.81), and understand (0.78).

Meanwhile, the second most frequent verb type is motion and rest verb either being used literally or metaphorically. In the collocate list for should and must, the only motion and rest verb type is take occurring 3.23 times per one million words, in should it co-occurs 1.63 times per one million words and it co-occurs with must 1.60 times. There is no significant difference in terms of co-occurrence frequency between should and must. Some uses of take as the right collocate of should are recorded in the figure 1.

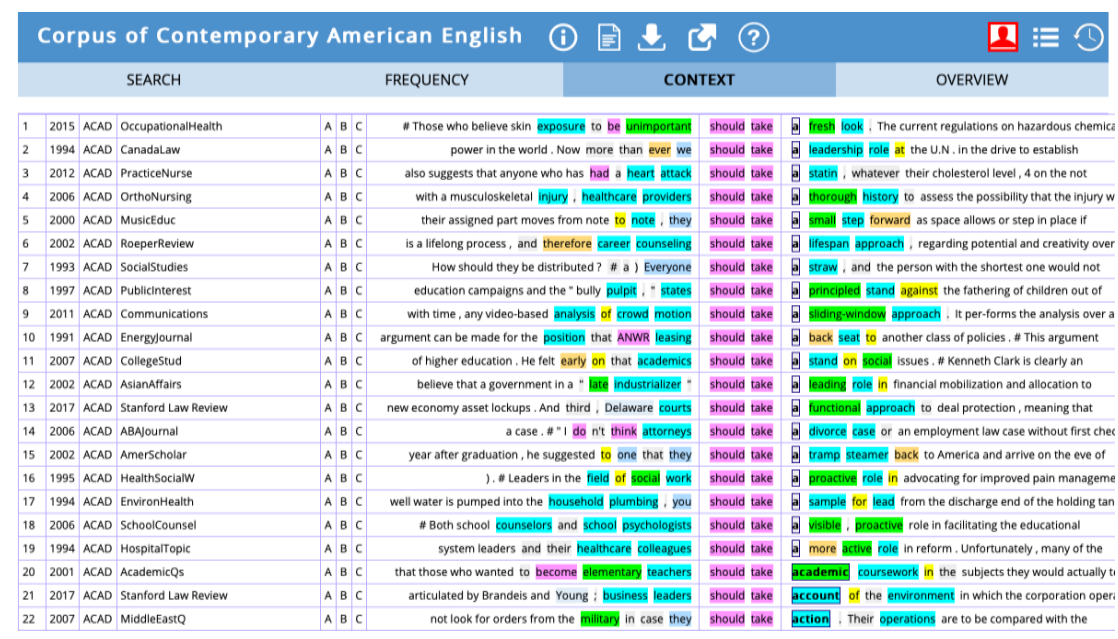

Figure 1. Concordances of should take 
Figure 1 presents some examples of should take concordances in which, as is seen from the figure, some use of take relates to the expression take into account and take into consideration. These two expressions are commonly used in academic context, as they are associated with thinking activity. Interestingly there is none of them shows the use of take literally showing motion-related activity. It is assumed that this motion and rest verb type is used in academic context metaphorically to refer to a certain action, e.g., take place, take into account, etc.

As for the third most frequent, there is comparing verb type. In the corpus under study, the verb belongs to this type is include, occurring 2.74 times per one million words. The use of comparing type in scientific context is predictable because it enables the comparison of theories, methods, data, etc, to state exclusion and inclusion. The use of this type to co-occur with necessity and obligation modals is to emphasize the inclusion or the exclusion. Some of the search results are displayed in figure 2 to provide clear instances of the use of include exhibiting inclusion in academic text.

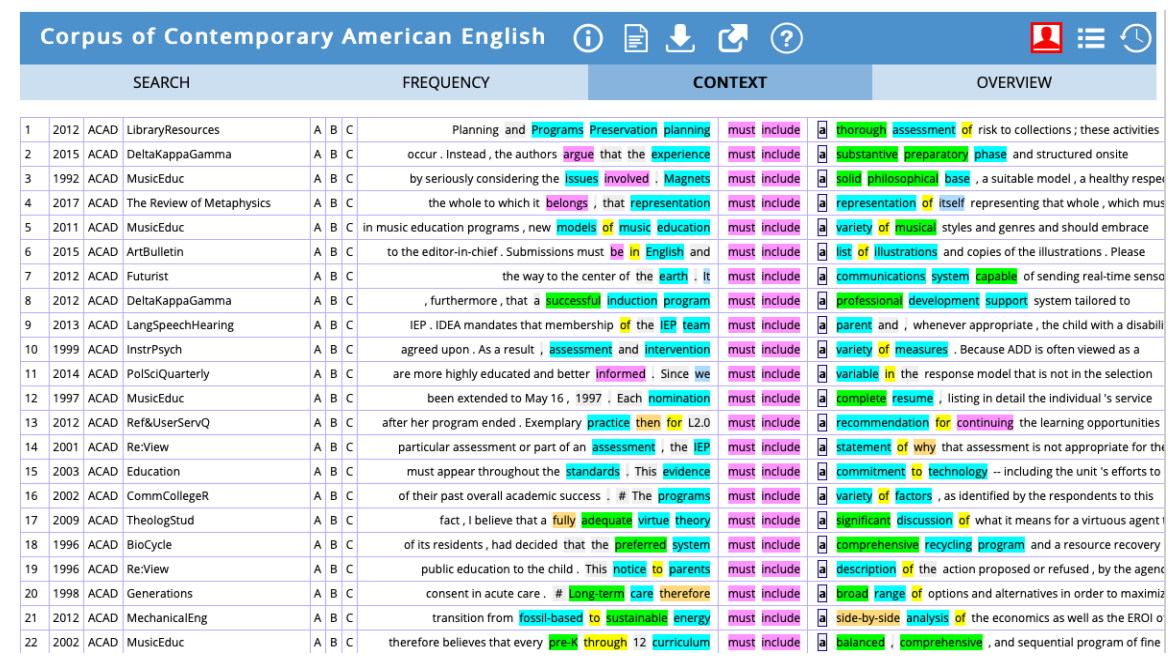

Figure 2. Concordances of must include

Other verb types found as the collocates of should and must are affect, giving, happening, using, and social contract. For affect type, there is only one verb found, that is make, occurring 2.09 times per one million words in COCA academic subcorpus. Giving type (verb provide) occurs 2.01 times per one million words. The rest of the verb types also comprises one verb found in the corpus, such as do belongs to happening (occurring 1.76 times per one million words), use belongs to using (occurring 0.74 times per one million words) and work belongs to social contract (occurring 0.74 per one million words).

\subsection{The Dynamic Use of Necessity and Obligation Modals in Academic Discourse and Beyond}

Academic discourse (e.g., research articles, theses, etc.) is known to present or deliver scientific facts or findings. In practice, there seem to be some cases in which the findings are obscure so the authors need to tone down the statement to avoid opposition. This can be done through the use of hedging system (Crompton, 1997; Hardjanto, 2016; Hyland, 1994, 1998; Sanjaya, Sitawati, \& Suciani, 2015). Hedging refers to any linguistic units used to mark the lack of commitment to 
the truth-value of proposition (Hyland, 1998, p. 1). In English, some of the possible ways to hedge author's statement is by using modals, e.g., can, could, may (Hardjanto, 2016; Hyland, 1994, 1998; Sanjaya et al., 2015). The function of hedging is in accordance with the nature of modals as the manifestation of modality in a way that it also deals with the possibility, prediction, necessity, etc., something that is not factual (Lyons, 1977; Palmer, 1990). This is in line with Hyland (1998, p. 1) stating that hedging is part of epistemic modality to demonstrate unwillingness to make commitment to the truth of proposition. The use of modals, thus, is inevitable and ubiquitous in nearly all text categories, including academic text, even though a particular text might use it more frequently than others.

Interestingly, the smaller frequency of necessity and obligation modals in academic text might indicate something. As stated by Brezina (2018), even the absence of a linguistic unit might signal something in corpus analysis. Biber \& Quirk, (2012) state that the smaller frequency of modals of necessity/obligation has something to do with the effort to avoid face threatening force resulted from obligation meaning. It demonstrates that the use of necessity and obligation modals in the academic text is not as significant as other modals. Regarding the use of necessity and obligation modals in academic text, it is found that should is the highest, followed by must, have to, shall, be supposed to, and have got to. It is important to note that the first and second most frequent modals are should and must classified as core modals. Sociolinguistically, core modals are preferable in certain circumstances due to its prestige (Leech et al., 2009) and its widespread usage across registers and dialects. Besides, reflecting to the nature of language used in academic context, it is evident that academic authors tend to use core modals, the unmarked forms or the canonic forms of modality system. On the contrary, quasi-modals such as have to, be supposed to, have got to are not as frequent as should and must because quasi-modals are the typical features of colloquialization (Leech et al., 2009).

Previous corpus investigation using Survey of English Usage (SEU) and LOB corpus shows that will and can occur twice more often in spoken English than in written English (Coates, 1983). In addition, it also presents that may and must are the only modals that can be found more frequently in written English than in spoken English (Coates, 1983, p. 24). It is not surprising that in the corpus used in this study, differs from fiction and news texts, core modal must has higher frequency than quasi-modal have to. Another relevant proof can be seen from the high frequency of be going to in spoken language (COCA) and the higher frequency of have to compared to must in all other text categories (fiction and news). According to Baker (2011) and Oktavianti (2019), there are some modals that show a tendency to remain constant known as lockwords, including can, could, would, and some others. None of these modals, however, are modals expressing necessity and obligation. Apart from that, the highlighted point is all lockwords of modal system are core modals so it is irrefutable that core modals are more preferable and desirable to use compared with other modality manifestations, such as quasimodals.

There is, however, an abnormality in relation to modal shall. Although it is a core modal, but over time the use of shall is dramatically decreasing in nearly all text categories and all instances of language use. The meaning of shall is basically the strongest of all necessity/obligation modals. According to Tagliamonte (2013, p. 123), shall originally express necessity/obligation in its earliest use. Based on the Historical Thesaurus of English (2016), both future-related meaning and necessity meaning conveyed by shall since its use in Old English, along with some other 
meanings. The thesaurus demonstrates that obligation and future meaning are the meanings embodied by shall up to this day. Interestingly, its lose of some other meanings is parallel with the declining usage as recorded in COCA since 1990, as illustrated by figure 3 .

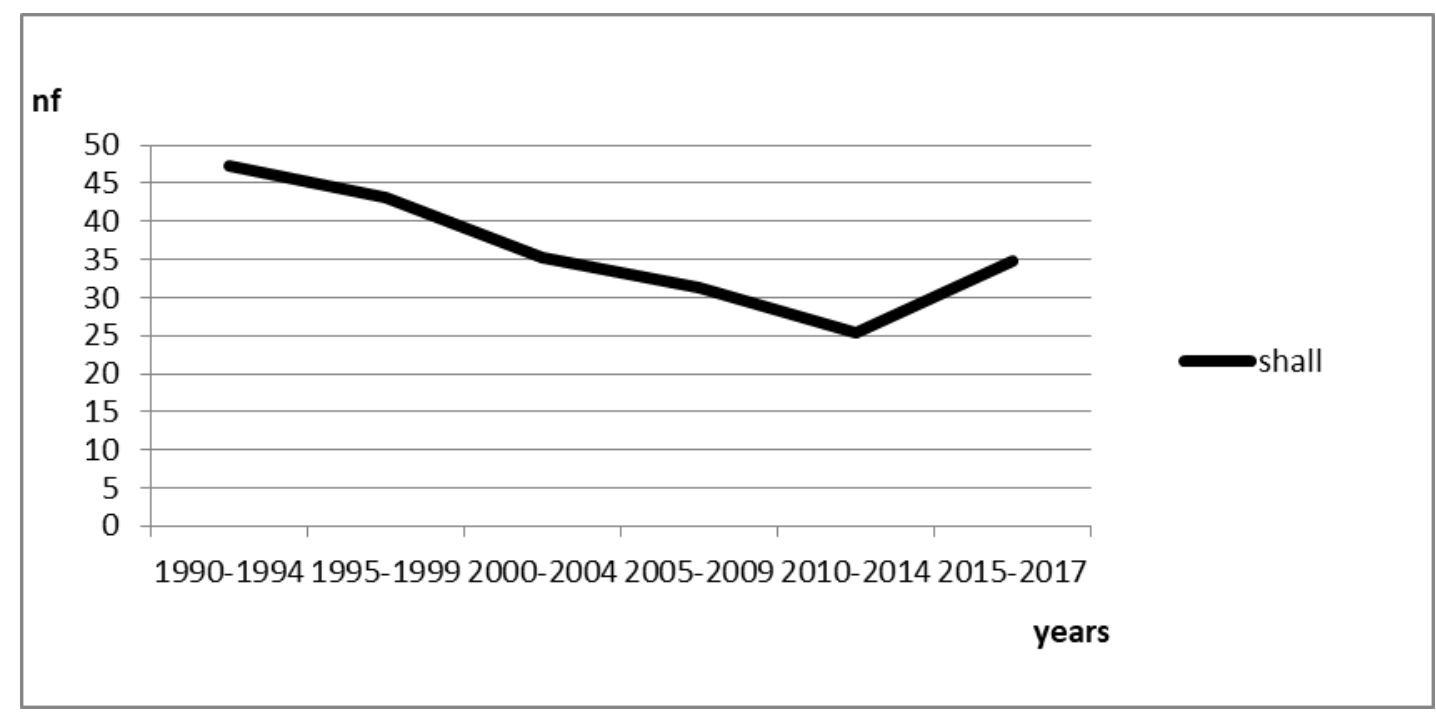

Figure 3. The use of shall from 1990-2017

Figure 3 presents the normalized frequency of shall usage over time, from 1990-2017, showing a tendency to fall off, but as of 2015 onwards there seems to be some escalation. This proves that the use of modals is as dynamic as the society using them.

The last two modals of necessity/obligation in this study are be supposed to and have got to having the least frequency of usage. As previously stated, it has something to do with colloquialization, which is not a typical characteristic of academic texts. The following table presents the different normalized frequencies of quasi-modals have to, be supposed to, and have got to in spoken and written English based on data gathered from COCA.

Table 7. Frequency (nf) of quasi-modals in speech and writing (COCA)

\begin{tabular}{|l|l|l|}
\hline Modals & Speech & Writing \\
\hline have to & 175 & 29 \\
\hline be supposed to & 1508 & 695 \\
\hline have got to & 81 & 46 \\
\hline
\end{tabular}

Table 7 comprehensibly provides empirical basis for the claim that there is a distinct characteristic of spoken and written English including modals choice in different media. It is evident that quasi-modals are preferable in speech rather than in writing.

This elaboration attempts to demonstrate that there are at least two plausible reasoning of the least frequency of necessity and obligation modals in academic context. First, it is related to the English-speaking society in general. Mcenery (2018) says that there is a tendency of change in the society related to the expression of necessity and obligation. Furthermore, McEnery argues that the characteristics that change into more democratic one also affect the choice of linguistic units used by the members of the society. This corresponds to what Deakin (2005) claims. 
Deakin proves that during 1939-2000 there is a significant change in the democratic way of life of British people: they are getting more actively participating in many aspects. It is seen in the comparison of all modality expressions recorded in COCA and British National Corpus (BNC), necessity/obligation is the smallest one (Oktavianti, 2019). The use of modals expressing necessity/obligation always has the lowest frequency in COCA and BNC, signaling that this sort of expression is not that significant in everyday life, compared to other modality expressions, such as prediction and possibility. Moreover, theoretically, academic texts purport to presents networks of cause and effect, thus presents facts as objective as possible. The use of modal, thus, is not the main concern. Thirdly, the use of modals lays on the context, and hence they are adjusted to the nature and characteristics of the context. Academic texts serve as the scientific work to present scientific ideas or discussions. To serve the function, standard language is selected to provide wide coverage of readers. Besides, it also uses technical or specific terms for the purpose of inclusion. As stated by Biber \& Gray (2016), language used in academic context is obtuse because of using technical languages understood by the community. Hence, this act results in the prestige of the language. It affects other choices of linguistic units, restricted to those from standard form and are able to show prestige when they are written. It is evident then core modals should and must enacting as the standard form of modals occupy the highest frequencies (except shall) and quasi-modals have lower frequencies.

\section{Conclusion}

This study found that among six modals of necessity/obligation under study, should and must, the core modals, are the most frequent ones in academic texts, followed by have to, shall, be supposed to, and have got to. Based on the corpus, modals of necessity/obligation should and must in academic context frequently co-occur with have in must have and should have. As with the verb type, thinking verbs occupy the most frequent verb type as the collocates of the modals. It demonstrates that in writing academic text, some thinking activities are involved, in which it really is. Other verb types are classified rather equally, showing that none is really dominant, and emphasizing that thinking type is quite significant as the collocates of necessity/obligation modals. In relation to the dynamic use of necessity/obligation modals in academic texts, there is a tendency that certain modals are more frequent than the others. Academic texts merely allow the use of Standard English, resulting in the more restricted choice of linguistic devices, including modals. Hence core modals are more frequently used in academic context than quasimodals, making it reasonable to have core modals should and must occupying the most frequent modals of necessity/obligation and quasi-modals be supposed to and have got to occupying the least frequent ones.

\section{References}

Allen, R. (1980). Socrates and legal obligation. Minneapolis: University of Minnesota Press.

Azar, B., \& Hagen, S. (2016). Understanding and using English grammar. London: Pearson Education.

Baker, P. (2011). Times may change, but we will always have money: Diachronic variation in recent British English. Journal of English Linguistics, 39(1), 65-88.

Bednarek, M., \& Caple, H. (2012). News Discourse. London: Continuum. 
Biber, D., \& Conrad, S. (2009). Register, Genre, and Style. Cambridge: Cambridge University Press.

Biber, D., \& Gray, B. (2016). Grammatical Complexity in Academic English. Grammatical Complexity in Academic English. https://doi.org/10.1017/cbo9780511920776

Biber, D., \& Quirk, R. (Eds.). (2012). Longman grammar of spoken and written English. Harlow: Longman.

Brezina, V. (2018). Statistics in corpus linguistics a practical guide. Cambridge: Cambridge University Press.

Carrió-pastor, M. L. (2007). Cross-cultural Variation in the Use of Modal Verbs in Academic English. 27, 153-166.

Chafe, W. L. (1970). Meaning and the structure of language. Chicago: University of Chicago Press.

Coates, J. (1983). The semantics of modal auxiliaries. London: Croom Helm.

Collins, P. (2009). Modals and quasi-modals in English. Amsterdam: Rodopi.

Collins, P. (2014). Quasi-modals and Modals in Australian English Fiction 1800-1999, with Comparisons across British and American English. Journal of English Linguistics, 42(1), 730. https://doi.org/10.1177/0075424213512857

Crompton, P. (1997). Hedging in academic writing: Some theoretical problems. English for Specific Purposes, 16(4), 271-287. https://doi.org/10.1016/S0889-4906(97)00007-0

Daugs, R. (2017). On the development of modals and semi-modals in American English in the 19th and 20th centuries. Studies in Variation, Contacts and Change in English2, 19.

Davies, M. (2004). BYU-BNC (Based on the British National Corpus from Oxford University Press. Retrieved from https://www.english-corpora.org/bnc/

Davies, M. (2008). The Corpus of Contemporary American English (COCA) 560 million words. Retrieved from https://www.english-corpora.org/coca/

Deakin, N. (2005). Civil society. In P. Addison \& H. Jones (Eds.), A Companion to Contemporary Britain 1939-2000. Oxford: Blackwell Publishing Ltd.

Dixon, R. M. W. (2005). A Semantic Approach to English Grammar. Oxford: Oxford University Press.

Dudley-Evans, T. (1994). Academic text: The importance of the use and comprehension of hedges. ASp, (5-6), 131-139. https://doi.org/10.4000/asp.4054

Eastwood, J. (2002). Oxford Guide to English Grammar. Oxford: Oxford University Press.

Gabrielatos, C., \& McEnery, T. (2005). Epistemic modality in MA dissertations. Lengua y Sociedad: Investigaciones Recientes En Lingüística Aplicada, (Lingüística y Filología no. 61), $311-331$.

Gahér, F. (2003). Logical, scientific and real possibility. In H. Rott \& V. Horák (Eds.), Possibility and reality. Frankfurt: Ontos Verlag.

Hardjanto, T. D. (2016). Hedging Through the Use of Modal Auxiliaries in English Academic Discourse. Jurnal Humaniora, 28(1), 37. https://doi.org/10.22146/jh.v28i1.11412

Hinkel, E. (2009). The effects of essay topics on modal verb uses in L1 and L2 academic writing. Journal of Pragmatics, 41(4), 667-683. https://doi.org/10.1016/j.pragma.2008.09.029

Historical Thesaurus of English. (2016). Retrieved from https://ht.ac.uk

Hykes, J. M. (2000). A comparison of the use of modal verbs in research articles by professionals and non-native speaking graduate students Part of the Bilingual, Multilingual, and Multicultural Education Commons, English Language and Literature Commons, and the 
First and Sec. Retrieved from https://lib.dr.iastate.edu/rtd/7929

Hyland, K. (1994). Hedging in academic writing and EAF textbooks. English for Specific Purposes, 13(3), 239-256. https://doi.org/10.1016/0889-4906(94)90004-3

Hyland, K. (1998). Hedging in Scientific Research Articles. https://doi.org/10.1075/pbns.

Hyland, K. (2009). Academic Discourse English in a Global Context. London: Continuum.

Leech, G., Hundt, M., Mair, C., \& Smith, N. (2009). Change in contemporary english: a grammatical study. https://doi.org/10.1017/CBO9780511642210

Leech, G., \& Short, M. (2007). Style in Fiction. New York: Pearson Longman.

Levin, B. (1993). English Verb Class and Alternations: A Preliminary Investigation.

Lyons, J. (1977). Semantics: Volume II. Cambridge: Cambridge University Press.

Mcenery, T. (2018). Corpus Linguistics: Methods, Analysis, Interpretation.

Mcenery, T., \& Kifle, N. . (2001). Epistemic modality in essays of second-language writers. In J. Flowerdew (Ed.), Academic Discourse. London: Routledge.

Murphy, R. (2012). English grammar in use. Cambridge: Cambridge University Press.

Oktavianti, I. N. (2019). Verba bantu modal bahasa Inggris: karakteristik, pemakaian dan perubahan. Universitas Gadjah Mada.

Oxford Dictionary of English [computer program]. (2014). Retrieved from https://apps.apple.com/us/app/oxford-dictionary-of-english/id439106200?mt=12

Palmer, F. R. (1990). Modality and the English modals (second edition). London: Longman.

Pavey, E. L. (2010). The structure of language. Cambridge: Cambridge University Press.

Rajalahti, K. (2006). The modals and the quasi-modals of necessity and obligation in the Phillipine and Singapor English. University of Tampere.

Sanjaya, I. N. S., Sitawati, A. A. R., \& Suciani, N. K. (2015). Comparing Hedges Used By English and Indonesian Scholars in Published Research Articles: a Corpus-Based Study. TEFLIN Journal-26(2), 209.

Stake, R. . (2010). Qualitative research: Studying how things work. New York: Guilford Press.

Tagliamonte, S. (2013). Roots of English. Cambridge: Cambridge University Press.

Tagliamonte, S., \& D'Arcy, A. (2007). The modals of obligation/necessity in Canadian perspective. English World Wide, 28(1), 47-78.

Yamamoto, N. (1999). The use of modals in ESL academic writing. California State University.

Yang, X. (2018). A Corpus-based Study of Modal Verbs in Chinese Learners' Academic Writing. English Language Teaching, 11(2), 122. https://doi.org/10.5539/elt.v11n2p122

Zimmerman, M. J. (1996). The concept of moral obligation. Cambridge: Cambridge University Press. 